\author{
BULETINUL INSTITUTULUI POLITEHNIC DIN IAŞI \\ Publicat de \\ Universitatea Tehnică „Gheorghe Asachi” din Iaşi \\ Volumul 67 (71), Numărul 2, 2021 \\ Secţia \\ CONSTRUCȚII DE MAȘINI \\ DOI: $10.2478 /$ bipcm-2021-0008 \\ sciendo
}

\title{
EXPERIMENTAL INVESTIGATION ON ASSEMBLY PROCESS FOR HIGH PRESSURE INJECTION PUMP COMPONENTS
}

\author{
BY
}

\section{DIANA PETRONELA BISTRICEANU* and CARMEN BUJOREANU}

\author{
"Gheorghe Asachi" Technical University of Iaşi,
}

Faculty of Mechanical Engineering, Iaşi, Romania

Received: March 26, 2021

Accepted for publication: May 24, 2021

\begin{abstract}
The sealing gaskets are mechanical systems that seal and fill the gap between two or more jointed surfaces. The gasket have been created and designed to prevent leaks that can occur between surfaces subjected to compression and also, to prevent contamination with dust, mud or other impurities from outside of the system. The applicability area of these gaskets has increased visibly and they are currently used in a full range of equipment, such as mechanical transmissions, machines for terrain works, equipment production, etc. The way that seals help to fix and connect the mechanical assemblies, their stress resistance and their durability over the time have been studied by literature. The paper presents the influence of the components assembly in a high-pressure pump and its impact on sealing. Using the Taylor Hobson measurement system and scanning electron microscopy we were able to find out the composition of the gasket studied and determine the dimensional variations, mainly due to the assembly process.
\end{abstract}

Keywords: gasket; sealing; Taylor Hobson system; assembly; high pressure injection pump; Scanning Electron Microscopy.

*Corresponding author; e-mail: Bistriceanu.dianna@yahoo.com (C) 2021 Diana Petronela Bistriceanu et al.

This is an open access article licensed under the Creative Commons Attribution-NonCommercialNoDerivatives 4.0 International License (CC BY-NC-ND 4.0). 


\section{Introduction}

The main assemblies of the diesel pump are the front plate, housing, driveshaft, gasket and hydraulic head. The gasket is the component in the high pressure pump that helps the sealing, prevent leakage from the pumps (Bistriceanu and Bujoreanu, 2019a; 2019b).

The sealing gaskets are mechanical systems that seal and fill the gap between two or more jointed surfaces (Gasket Handbook, 2017; Toshiyuki and Ogata, 2002).

The gasket have been created and designed to prevent leaks that can occur between surfaces subjected to compression and also, to prevent contamination with dust, mud or other impurities from outside of the system (Aibada et al., 2017).

The applicability area of these gaskets has increased visibly and they are currently used in a full range of equipment's, such as mechanical transmissions, machines for terrain works, equipment production, etc. (Drago, 2008).

According to the classification of the European Sealing Association, the gaskets are metallic and non-metallic (also, called soft seals) manufactured by the compaction process in which the mixture, a wide variety of fibers (carbon, cellulose, glass and lyts) are compressed between two cylindrical drums.

The way in which the seals help to fix and mechanically connect assemblies, withstand stress and durability over time has also been studied by literature (Speck, 2005; Paunescu, 2006).

The sealing by compression fittings can be performed by screws, their force must be large enough to prevent leakage and filling the irregularities between the joint surfaces by making the sealing, this has also been studied by literature.

This paper presents the assembly process of the components from a high-pressure pump and its impact on sealing (Hoyes and Bond, 2007). The geometry of the seal, the properties and material from which they are made are adapted according to the conditions at which they must withstand. Temperature, relative movements, vibrations and pressure differences are environmental factors that can influence sealing (Gonzalez, 2017).

\section{Methodology and Materials}

The assembly mode of the pumps is carried out in several stages. The term: 'ensemble' indicates both the sum of all the components united or caught, but also includes the screwing process of all the screws that maintain together these parts. According to the standard EN 1993-1-8, only screws of classes 8.8 and 10.9 can be pre-tensioned and the utilization of other classes is prohibited (Couchaux, 2010). 
Also, EN 1993-1-8 pre-tensioned screws must have a minimum number of four thread wires on top and a thread wire under the surface of the nut. Besides, another standard EN 1090-2 imposes a minimum screw size for those used in structural applications M12 (Nijgh, 2006).

M12 screws are among the most used screws being used in metal constructions, for joining because they have a good resistance to traction, hardness, breaking elongation, resistance to test load. After the condition of the material in the finished product there are screws without heat treatment and screws with heat treatment, as the screws used in assembly of the pumps (Nijgh, 2006).

The components of a high-pressure pump must have a certain degree of cleaning directly from the supplier (Abid and Hussain, 2008).

The composition of the studied seal is made of $\mathrm{Cr}$-Si and elastomers. Our paper presents an experimental analysis of the jointing process and the impact that the gasket and screws have over the sealing of the pump.

Some components have certain manufacturing processing and therefore it is important that after each processing the degree of cleanliness is respected. Very important is that all the components that enter the high pressure pumps fall into the required cleaning class. The assembly of components is carried out in a clean room $(\mathrm{Xu}, 2007)$. The clean room represents an environment with a low level of polluting factors in which it operates under predetermined and carefully controlled safety rules. The air is permanently filtered to remove particles and impurities that can harm activity in the specific field. All relevant parameters (temperature, humidity, pressure, speed) are controlled according to Europa- ISO 14644 and ISO 14698 (http://www.xlab.ro/ro/Prezentare_concept_camere_curate). Clean rooms are used in different fields of activity: public health systems, pharmaceutical industry (drug production and packaging), chemical industry, food industry, fine mechanic industry, aerospace industry. The purity of the air in the clean working area is conventionally defined by the cleaning class which represents the maximum number of particles with a size starting from $1 \mu \mathrm{m}$. The components must be within the permissible limits because any deviation from the drawing can have negative effects in the assembly and functionality of high pressure pumps.

The assembly process is carried out in several stages depending on each component assembled. The assembly of the housing, driveshaft, gasket and front plate are carried out with the help of Janome screwdrivers that control torque and angle for each screw (Meher and Rao, 2006).

From Fig. 1, we can see the order of the components from which is built a high pressure pump (Bistriceanu and Bujoreanu, 2019a; 2019b).

The conditions of the components/ surfaces but also the dimensional characteristics requirements have a very important role in the assembly of an ideal pump. Any deviation from permissible limits may have a negative impact on the engine pump (Bistriceanu and Bujoreanu, 2019a; 2019b). 


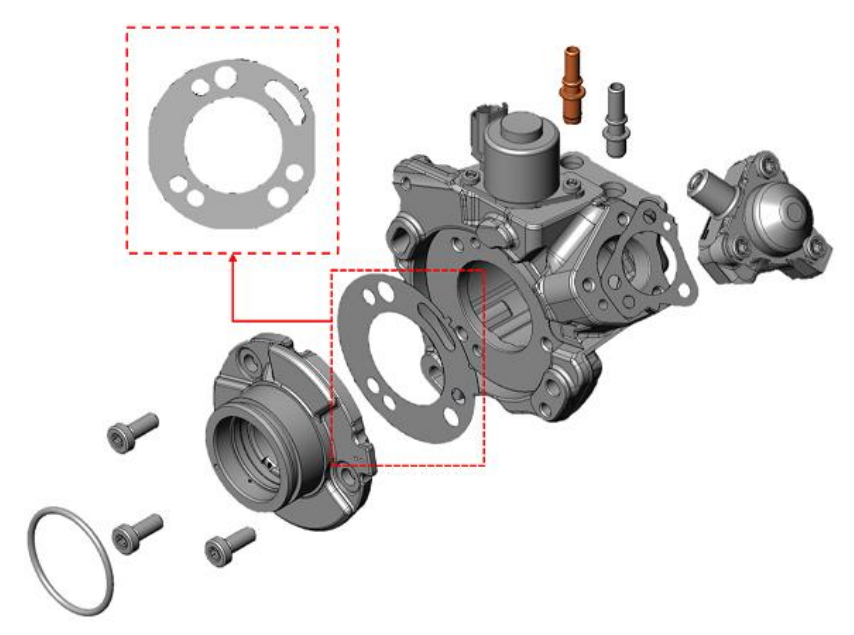

Fig. 1 - The components of an injection pump.

\section{Results and Discussion}

Our investigation for the determination of dimensional deviations, due to assembly process, was performed using the Taylor Hobson measurement system.

Measurements on 50 Front Plate

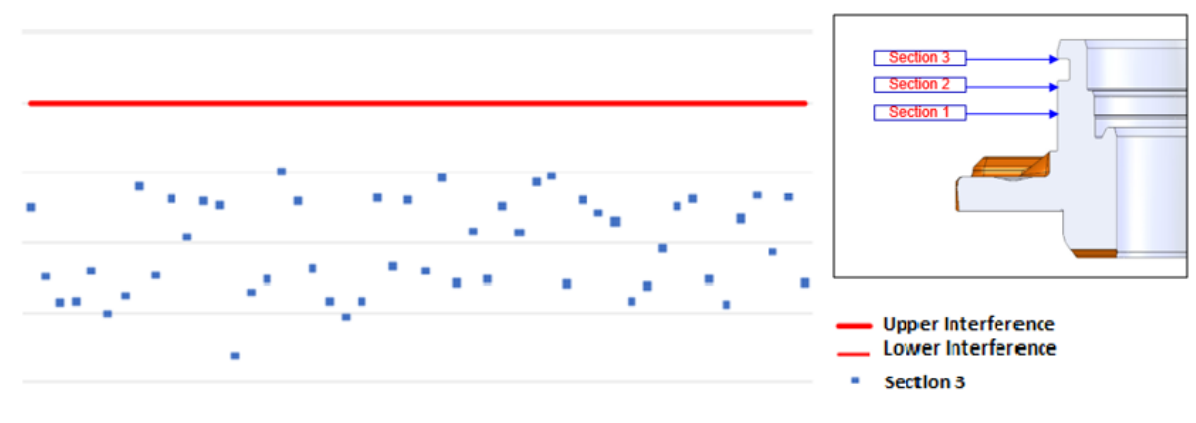

Fig. 2 - Measurements on 50 Front Plate on 3 heights. 
To determine the condition of the components, if the parts from incoming are within the allowed limits, fifty front plates on three heights were measured. It has been shown that the components are within the necessary limits. Also, various cleaning tests were carried out to determine the cleaning degree of the components and collect the particles.

Using the SEM (Scanning Electron Microscope) device, different seals were analyzed to determine if the parts respect the required chemical composition (Cardey and Fleurentin, 2013).

From Fig. 2, we can see the results of 50 measurements performed by Taylor Hobson system on 3 heights to determine if the components meet acceptable limits. Measurements were made on fresh components.

Also, a very important component is the gasket, because it helps the pump to operate with different parameters, preventing the fuel to leak from inside to outside (Jiaa and Dornfeld, 1990).

Using the Energy Dispersive X-ray Spectroscopy (EDX), we are able to determine the composition of a sample. Not only relative amounts of each atom can be measured, but the distribution of the atoms in our samples can be mapped. The EDX can be used for the analysis of metals, powders, and liquids. It is used extensively in the steel and nonferrous alloy industries (Smith and Verhappen, 2010).

Fig. 3 presents the chemical analysis of a gasket that was carried out using the semi-quantitative EDX (Energy-dispersive X-ray) Spectrometry.

Chemical composition of steel

$\mathrm{Cr}-\mathrm{Ni}$

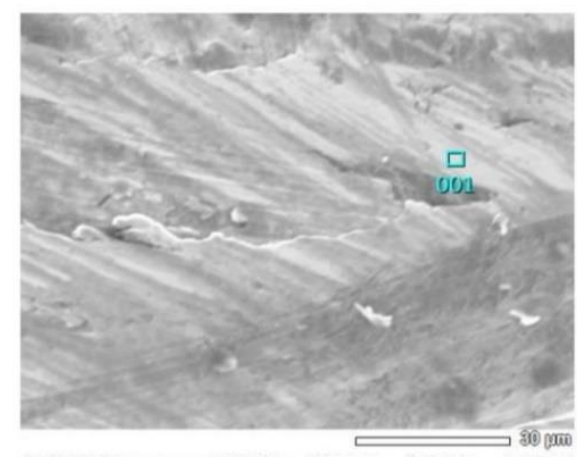

Fig. 3 - Chemical composition of steel.
Chemical composition of rubber

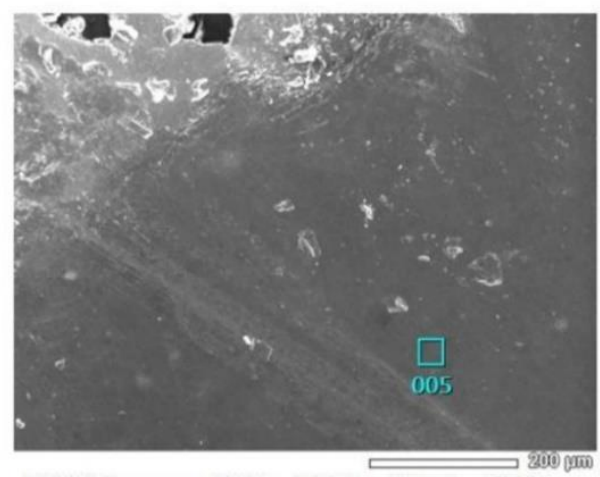

The main alloy elements for this type of material comply with the requirements of EN10088-2 for stainless steel. According, to the British 
Stainless Steel Association, the chemical composition of flat stainless steel products used for general purposes contain in total: 97 stainless steel grades, including 25 ferritic, 14 martensitic, 2 precipitation hardening, 44 austenitic and 12 austenitic-ferritic (duplex) grades (https://www.bssa.org.uk ).

Using EDX, Fig. 4 shows the coating thickness for this gasket. Thermoplastic elastomer (TPE) is used to cover the seal.

The reason consists in the elastic properties with similar performance as the elastomers, extrusion processing is simple and similar to plastics. In addition, the TPE substrates allow (through coextrusion) the coating of surfaces subjected to friction with a sliding TPE material (Astalosch and Atanasiu, 2012).
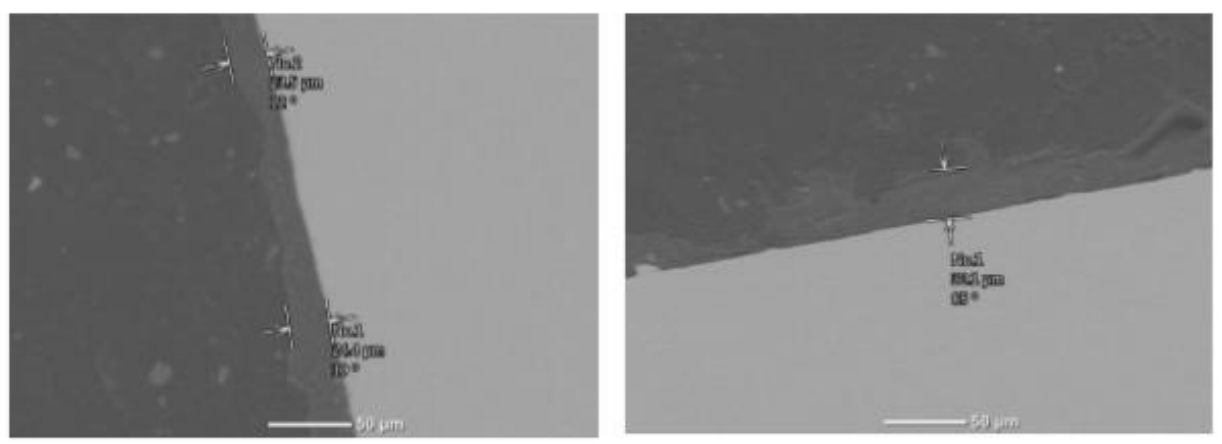

Fig. 4 - The coating layer.

\section{Conclusions}

The conditions of the components/ surfaces but also the dimensional characteristics requirements have a very important role in the assembly of an ideal pump. Any deviation from permissible limits may have a negative impact on the engine pump. The geometry of the seal, the properties and the materials from which they are made are adapted according to the conditions under which they must withstand. Temperature, relative movements, vibrations and pressure differences are environmental factors that can influence sealing.

Using the Taylor Hobson measurement system and scanning electron microscopy we were able to find out the composition of the gasket studied and determine the dimensional variations, mainly due to the assembly process. Given that these components are in permissible limits and respect the requirements of cleanliness we can say that all tested components meet the imposed requirements. 


\section{REFERENCES}

Abid M., Hussain S, Bolt Preload Scatter and Relaxation Behaviour During Tightening a 4 in-900\# Flange Joint with Spiral Wound Gasket, ARCHIVE Proceedings of the Institution of Mechanical Engineers Part E, Journal of Process Mechanical Engineering 1989-1996, 222, 2, 123-134, May 2008.

Aibada N., Manickam R., Gupta K.K., Raichurkar P., Review on Various Gaskets Based on the Materials, their Characteristics and Applications, International Journal on Textile Engineering and Processe, 3, 1, February 2017.

Astalosch C., Atanasiu C.G, Mechanical Properties Determination of Type Covering for Automotive Door Sealing's, 2012.

Bistriceanu D.P, Bujoreanu C., Experimental Analysis on High Pressure Pump Sealing Gasket, Bul. Inst. Polit. Iasi, 65 (69), 1 (2019a).

Bistriceanu D.P., Bujoreanu C., Influence of Sealing Gasket Distortion on Diesel Engine Injection Pump Mountability, ModTech, IOP Conf. Ser.: Mater. Sci. Eng., 591, 012003, 2019b.

Cardey P.F., Fleurentin A., Tribological Advantages of Nitrocarburizing over Carbonitriding: Influence of the Composition and Architecture of the Compound Layer, 40th Leeds-Lyon Symposium on Tribology \& Tribochemistry Forum, September 4-6, 2013, Lyon, France.

Couchaux M., Behavior of Bolted Circular flange Joints, PhD Thesis, INSA of Rennes, 2010.

Drago J., World Pumps, European Committee of Pump Manufacturer, 498, 25-27 (2008).

Gonzalez C., Machine Design, 7 Common Failures of Hydraulic Seals, Jul 2017.

Hoyes J.B., Bond S., Sealing Technology, 8, 11-14 (2007).

Jiaa C.L., Dornfeld D.A., Wear, 139, 2, 403-424 (1990).

Meher K.K., Rao A.R., Optimal Foundation Design of a Vertical Pump Assembly, Journal of Sound and Vibration, April 2006, 291, 3-5, 4, 1269-1277 (2006).

Nijgh M., Loss of Preload in Pretensioned Bolts, PhD Thesis, 2006.

Paunescu M., Experimental Research Regarding Gaskets Durability, International Journal of Fatigue, September 2006, 28, 9, 1081-1086 (2006).

Smith A.C., Verhappen I., Chapter 23 - Chemical Analysis: Spectroscopy, Instrumentation Reference Book (Fourth Edition), 341-362, 2010.

Speck A.J., Mechanical Fastening, Joining, and Assembly, 2015.

Toshiyuki S., Ogata N., ASME Pressure Vessels and Piping Conference, 115-127, 2002.

$\mathrm{Xu} \mathrm{T}$. ., Characterization of minienvironments in a clean room: Design characteristics and environmental performance, Elsevier, 42, 8, 2993-3000, August 2007.

$* *^{*}$ Gasket Handbook, Fluid Sealing Association (FSA 1000) 1st Edition, pp. 138, 2017. http://www.stoneleigh-eng.com/gaskets.html

http://www.xlab.ro/ro/Prezentare_concept_camere_curate

https://www.bssa.org.uk 


\section{INVESTIGAȚII EXPERIMENTALE ASUPRA PROCESULUI DE ASAMBLARE A COMPONENTELOR POMPEI DE ÎNALTĂ PRESIUNE}

\section{(Rezumat)}

În această lucrare este prezentată o investigaţie asupra procesului de asamblare a componentelor unei pompe de înaltă presiune. Cele mai importante ansamble care alcătuiesc pompa de înaltă presiune sunt: carcasa, arborele de antrenare, placa frontală, şuruburile şi capul hidraulic. Garniturile sunt sisteme mecanice care sigilează şi umplu golul dintre două sau mai multe suprafețe articulate. Garnitura a fost creată și proiectată pentru a preveni scurgerile care pot apărea între suprafețele supuse comprimării și, de asemenea, pentru a preveni contaminarea cu praf, noroi sau alte impurităţi din afara sistemului. Garnitura ajută ca pompa să funcționeze în parametri diferiţi, împiedicând combustibilul de la ieșirea din interior spre exterior.

Folosind spectroscopia cu raze $X$ dispersivă a energiei, am reușit să determinăm compoziția unei garnituri împărţind-o în mai multe folii subțiri. Cu ajutorul sistemului de măsură Taylor Hobson şi SEM am reuşit să aflăm compoziţia garniturii studiate şi de a determina variaţiile dimensionale, datorate procesului de asamblare. 